\title{
EFFECT OF MILL SCALE AND FLY ASH WASTE ON THE PERFORMANCE OF CEMENT MORTAR
}

\author{
Shivam Nema ${ }^{1}$, Pranjali Soley ${ }^{2}$, Ansh Bhawsar ${ }^{3}$, Ashish Nim ${ }^{4}$ \\ ${ }^{1}$ Undergraduate, Civil Engineering Department, IES IPS Academy, Indore, Madhya Pradesh, India \\ ${ }^{2}$ Undergraduate, Civil Engineering Department, IES IPS Academy, Indore, Madhya Pradesh, India \\ ${ }^{3}$ Undergraduate, Civil Engineering Department, IES IPS Academy, Indore, Madhya Pradesh, India \\ ${ }^{4}$ Assistant Professor, Civil Engineering Department, IES IPS Academy, Indore, Madhya Pradesh, India
}

\begin{abstract}
This paper investigates effect of mill scale and fly ash wastes as a replacement of fine aggregate generally natural sand on the performance of cement mortar. Utilization of fly ash and mill scale in cement mortar production not only provides significant environmental benefits but also enhances performance of the cement mortar when used at optimum amounts. They may be used in the form of finely ground additive to replace part of aggregates in cement mortar. This study looked at the feasibility of mill scale and fly ash waste inclusion as partial aggregate replacement in normal cement mortar. Properties of cement mortar incorporating fly ash and mill scale waste as partial substitution for natural aggregate were investigated. The study involves six replacement levels of mill scale and fly ash wastes into cement mortar for each mix design. Mortar cubes are tested for strength, $\&$ water absorption. The partial replacement of fine aggregate by $M_{(3,30)}, M_{(5,30)}, M_{(8,30)}, M_{(10,30),} M_{(12,30)}, M_{(15,30)}$ ( $M$-mix of mill scale \& fly ash \%) improves the properties of normal mortar. In the design mix of industrial wastes produced, percentage of fly ash is kept constant $(30 \%)$ and mill scale is varied from 0 to $15 \%$ by weight of natural sand. The test results indicate that the mechanical properties of mill scale and fly ash modified mortar are improved to a great extent, whereas the water absorption is reduced as compared to that of plain mortar.
\end{abstract}

Keywords: Mill Scale, Fly Ash, Compressive Strength, Durability, Water Absorption, Density

\section{INTRODUCTION}

\subsection{General}

Mortar is a homogeneous mixture, produced by intimately mixing cementitious materials, water and inert materials, such as sand to the required consistency for use in building together with masonry units. It is a commonly used building material in various civil engineering works. Due to growing environment concern and the need to conserve energy, various research efforts have been directed toward the utilization of waste materials in cement mortar. With everincreasing environmental problems because of industrial waste products comes a great need to use these products in an appropriate manner to reduce health and environmental problems. The use of river sand as fine aggregate leads to exploitation of natural resources, lowering of water table and erosion of river bed. If fine aggregate is replaced by industrial wastes by optimum percentage and in specific size range, it will decrease fine aggregate content and thereby reducing the ill effects of river dredging and thus making concrete manufacturing industry sustainable. For this purpose, experimental investigation is carried out to produce data on the compressive strength of mortar with different percent replacement of a mixture fly ash and mill scale in varying percentages.

\subsection{Importance and Scope of Project}

Due to increasing rate of industrialization and urbanization, the amount and type of waste materials have increased accordingly. Many of the non-decaying waste materials will remain in the environment for hundreds; perhaps thousands of years. The non-decaying waste materials cause a waste disposal crisis, thereby contributing to the environmental problems. The problem of waste accumulation exists worldwide, specifically in the densely populated areas. Most of these materials are left as stockpiles, landfill material or illegally dumped in selected areas. Hence in order to overcome the above said the waste product should be employed as construction material. Thus present study involves replacement of fine aggregate used in cement mortar by mixture of mill scale and fly ash wastes by known percentages. Utilization of such industrial waste materials and by -products is a partial solution to environmental and ecological problems. Use of these materials not only helps in getting them utilized in cement, concrete and other construction materials, it helps in reducing the cost of cement and concrete manufacturing, but also has numerous indirect benefits such as reduction in land-fill cost, saving in energy, and protecting the environment from possible threat due to pollution. 


\subsection{Objective of Project}

The objectives of present study are described below.

- To select appropriate mill scale and fly ash waste mix proportion for modified cement mortar.

- To determine optimum content of mill scale- fly ash wastes as a replacement of fine aggregate.

- To investigate change in compressive strength of cement mortar with mill scale and fly ash wastes

- To study the density of modified mortar formed by utilization of different mix proportion of Mill Scale and Fly Ash waste.

\section{MATERIALS}

\subsection{Cement}

The cement used in investigation should be fresh, of uniform consistency and free of lumps and foreign matter. It should be stored under dry conditions and for as short duration as possible Cement used in the investigation was 43 grade ordinary Portland cement confirming IS 8112: 1989. The cement was tested and the physical properties of the cement were computed, the results obtained were within limit as specified in Indian Standards and are as follows: Normal Consistency -33\%, Initial Setting Time - 93 min And Final Setting Time $-485 \mathrm{~min}$, Specific Gravity $=3.15$, Density Of Cement - $3.10 \mathrm{gm} / \mathrm{cc}$, Fineness $-2800 \mathrm{~cm}^{2} / \mathrm{gm}$.

\subsection{Fine Aggregate}

Normal weight fine aggregate (sand) is the most common aggregate used in cement mortar. It should be clean, hard, strong, free of organic impurities and deleterious substances and relatively free of silt and clay. It should be inert with respect to other materials used and of suitable type with respect to strength, density, shrinkage and durability of the mortar made with it. Grading of the sand is to be such that a mortar of specified proportions is produced with a uniform distribution of the aggregate, which will have a high density and good workability and which will work into position without segregation and without use of high water content. The sand was sieved using $4.75 \mathrm{~mm}$ and the fraction passing $4.75 \mathrm{~mm}$ was used for all experiments The sand belongs to zone -II as per IS: 383-1970. The physical properties of fine aggregate were computed according to IS 383-1970 and results obtained are as follows: Fineness Modulus-2.83, Silt Content $-0.5 \%$, Specific Gravity - 2.65 .

\subsection{Fly Ash}

Fly ash is a waste obtained in tonnes from thermal power plants. It is a fine powder resulting from the combustion of coal, transported by the flue gases of the boiler and collected in the electrostatic precipitators (ESP). It is pozzolonic material and is widely used in the construction industry. There are basically two types of fly ash: class C (highcalcium fly ash) \& class F (low-calcium fly ash). The utilization of fly ash in cement mortar has multiple advantages such as cost reduction, energy saving, reduction in exploitation of natural resources etc.It has been accepted that when optimum content of fly ash is added in cement mortar or concrete improves both the strength and durability properties. Various tests per performed on fly ash according to Indian Standards. The physical properties of fly ash used in present experiment are as follow: specific gravity 2.3, density $2.13 \mathrm{gm} / \mathrm{cc}$.

\subsection{Mill Scale}

Mill scale is waste obtained from iron industry. It is generally produced during continuous casting soaking, reheating and rolling operations. This is relatively pure iron oxide with little contamination. It is a magnetic material consisting of iron in a typical range of $93-95 \%$. The material is porous, hard and brittle. On an average, every year, one single steel processing unit produces about 6500 to 8500 tons of mill scale \& almost 18-20 million metric tons of this material is produced every year. Most of the material is dumped in landfills. Most of the material is dumped in landfills Most of the material is dumped in landfills Most of the material is dumped in landfill.

\subsection{Water}

Water is an important component of cement mortar. When cement comes in contact with water, an exothermic reaction occurs and setting of cement starts. Water used in the mixing is to be fresh and free from any organic and harmful solution which will lead to deterioration in the properties of the mortar. Salt water is not acceptable but chlorinated drinking water can be used. Potable water is fit for use as mixing water as well as for curing. 


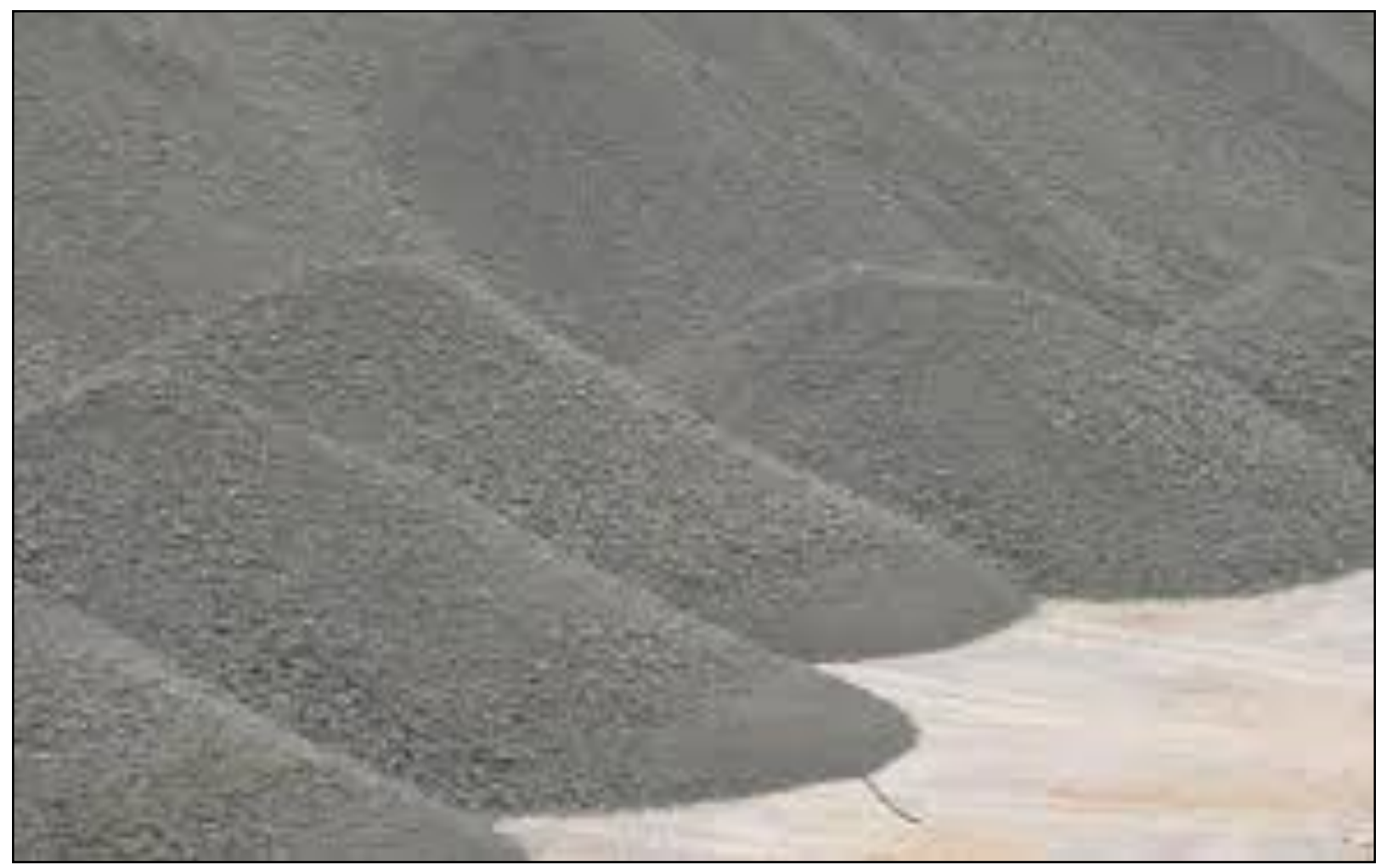

Fig 1 - Mill Scale Waste

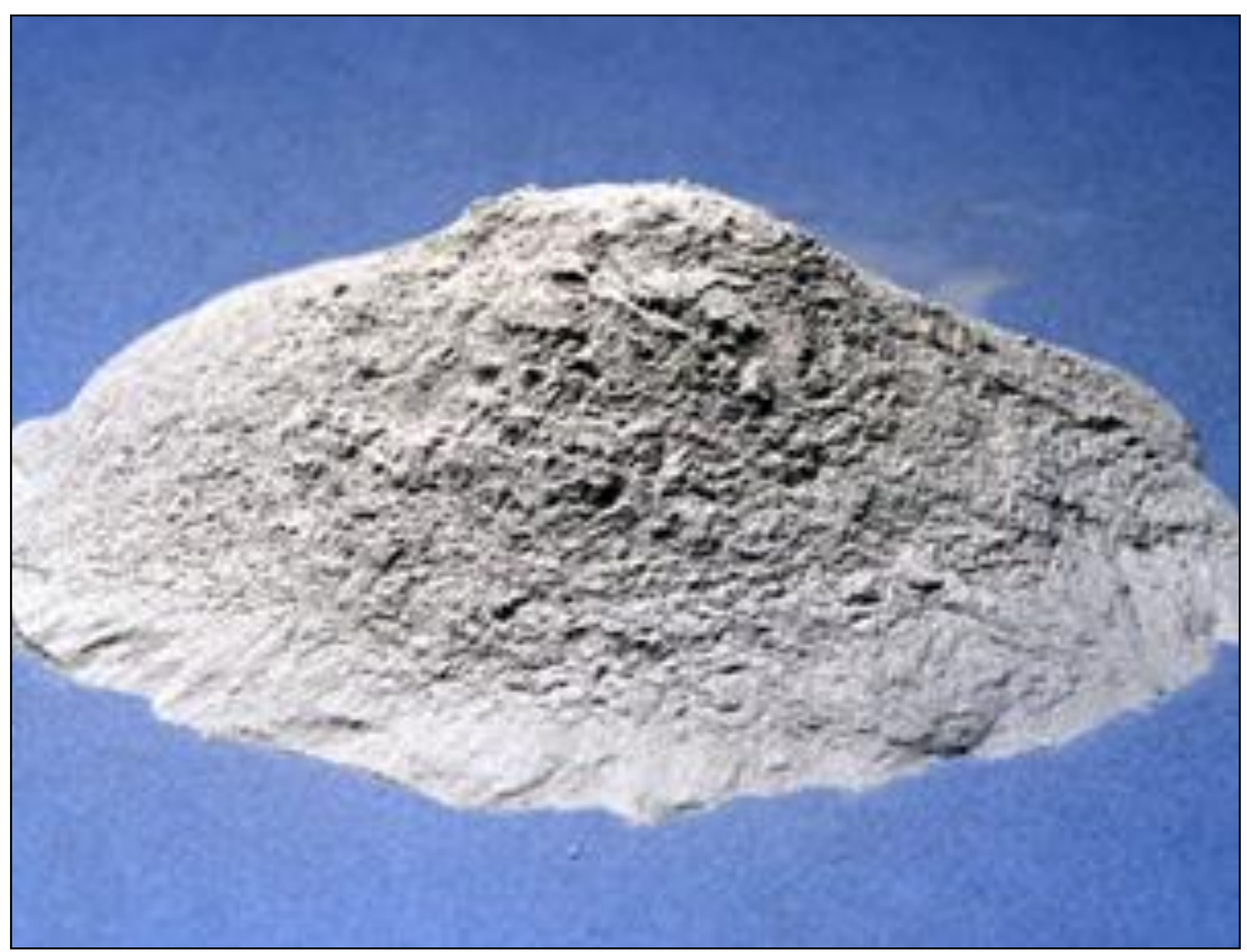

Fig 2 -Fly Ash Wastes 


\section{DESIGN MIX METHODOLOGY}

\subsection{Proportioning of Mill Scale-Fly ash Mixes.}

For experimental analysis various mill scale \& fly ash mixes were formed. Mixes of wastes are representated as $\mathbf{M}_{(\mathrm{X}, \mathrm{Y})}$. In this notation M Stands For Mix, subscript X denotes mill scale ( \%) \& Y denotes fly ash (\%) by weight of natural sand. The various proportions of mill scale and fly ash mixes used in present study are shown in table 1.

Table -1: Proportioning of Mill Scale-Fly ash Mixes

\begin{tabular}{|l|l|l|l|}
\hline S.No & Mix Designation & Mill Scale & Fly Ash \\
\hline & $\mathrm{M}_{(\mathrm{X}, \mathrm{Y})}$ & $(\%)$ & $(\%)$ \\
\hline 1 & $\mathrm{M}_{(03,30)}$ & 3 & 30 \\
\hline 2 & $\mathrm{M}_{(05,30)}$ & 5 & 30 \\
\hline 3 & $\mathrm{M}_{(07,30)}$ & 7 & 30 \\
\hline 4 & $\mathrm{M}_{(10,30)}$ & 10 & 30 \\
\hline 5 & $\mathrm{M}_{(12,30)}$ & 12 & 30 \\
\hline 6 & $\mathrm{M}_{(15,30)}$ & 15 & 30 \\
\hline
\end{tabular}

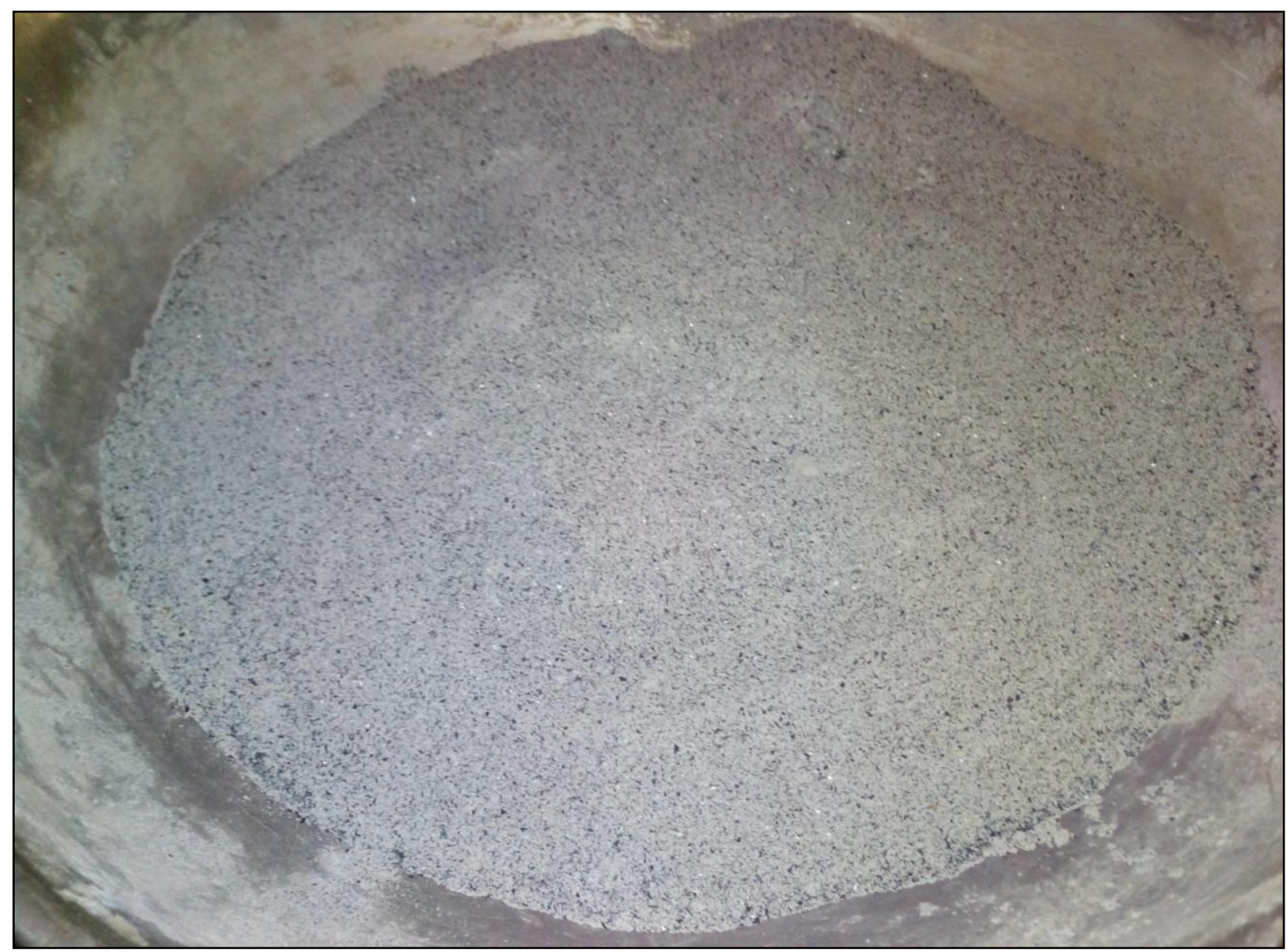

Fig 3- Mill Scale - Fly Ash Mix

\subsection{Design Mix Proportion for Various Mortar Sample (1:3)}

In the present study, various mortar samples were prepared by involving various mill scale and fly ash mixes. The proportion of different ingredients of modified mortar is shown in table 2. 
Table -2: Design mix proportion for modified Mortar Samples (1:4)

\begin{tabular}{|l|l|l|l|l|l|}
\hline $\begin{array}{l}\text { Mix } \\
\text { No }\end{array}$ & Mix Type & Cement & Sand & $\begin{array}{l}\text { MS+FA } \\
\text { Waste }\end{array}$ & Water \\
\hline A & $M_{(\mathrm{X}, \mathrm{Y})}$ & & & & \\
\hline A1 & $\mathrm{M}_{(00,00)}$ & 1 & 4 & 0 & 0.45 \\
\hline A2 & $\mathrm{M}_{(03,30)}$ & 1 & 3.67 & 0.33 & 0.45 \\
\hline A3 & $\mathrm{M}_{(05,30)}$ & 1 & 3.65 & 0.35 & 0.45 \\
\hline A4 & $\mathrm{M}_{(07,30)}$ & 1 & 3.63 & 0.37 & 0.45 \\
\hline A5 & $\mathrm{M}_{(10,30)}$ & 1 & 3.60 & 0.40 & 0.45 \\
\hline A6 & $\mathrm{M}_{(12,30)}$ & 1 & 3.58 & 0.42 & 0.45 \\
\hline A7 & $\mathrm{M}_{(15,30)}$ & 1 & 3.55 & 0.45 & 0.45 \\
\hline
\end{tabular}

\section{TESTS AND RESULTS}

\subsection{Compressive Strength Test}

In order to study the effect of mill scale and fly ash waste as partial fine aggregate replacement on the strength of mortar (1:4), cubes of size $70.6 \mathrm{~mm} \times 70.6 \mathrm{~mm} \times 70.6 \mathrm{~mm}$ were cast for different percentage of mill scale and fly ash waste and for 0\% waste for a mix have been cast in the laboratory For making the mortar cubes, IS 2250-1995 (Code of practice for preparation and use of masonry mortar)

An effort has been made here to compare the strength of cubes made up with different percentage of mill scale and fly ash waste to the respective strength of conventional cement mortar at the end of 7,14,21, 28\&56 days of curing and to have an idea about the optimum percentage of mill scale and fly ash waste which does not affect the strength of recycled mortar considerably. Water cement ratio adopted was 0.45 .

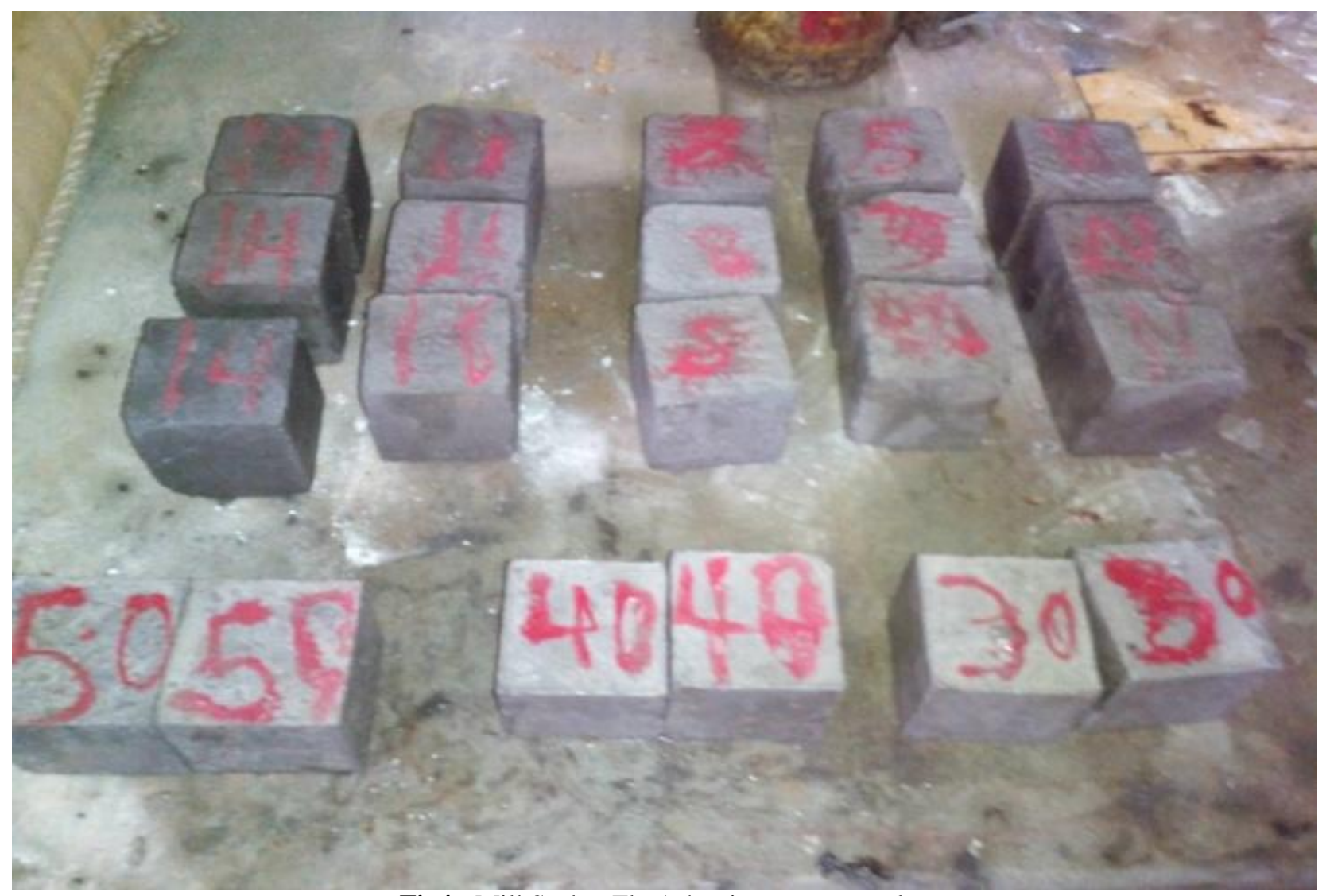

Fig4 - Mill Scale - Fly Ash mix mortar samples 


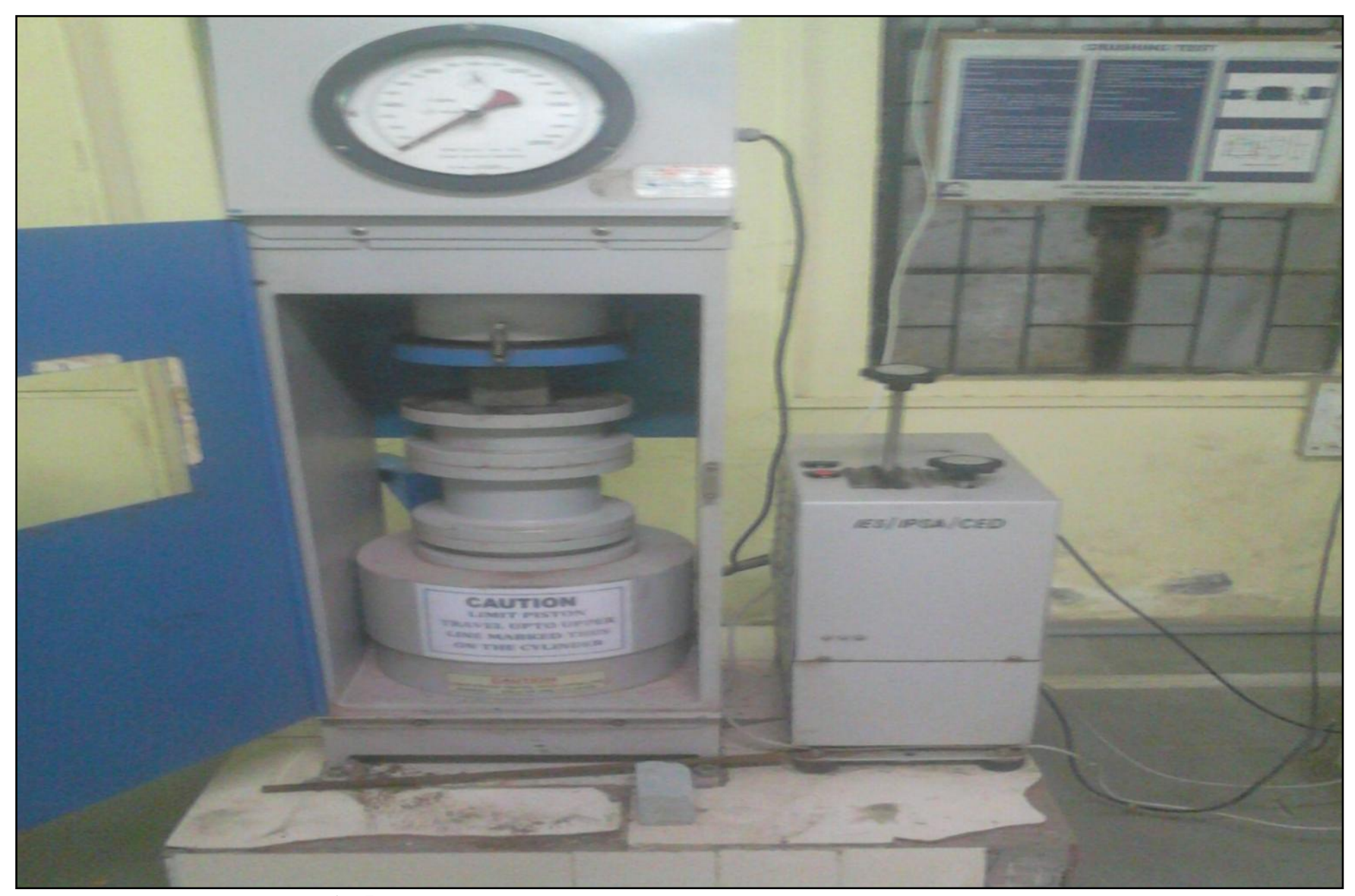

Fig 5 Test setup For Compressive Strength Test of Cement Mortar

Average Compressive strength of modified mortar samples were calculated after 7, 14,21,28,56 days curing and are shown in Tables below respectively.

Table -4: Average Compressive Strength of Mortar after 7 Days Curing

\begin{tabular}{|l|l|l|l|}
\hline S.No & $\begin{array}{l}\text { Mix } \\
\text { Designation }\end{array}$ & Mix Type & $\begin{array}{l}7 \quad \text { Days Average } \\
\text { Compressive Strength }\end{array}$ \\
\hline & & $\mathrm{M}_{(\mathrm{X}, \mathrm{Y})}$ & MPA \\
\hline 1 & $\mathrm{~A} 1$ & $\mathrm{M}_{(00,00)}$ & 20.2 \\
\hline 2 & $\mathrm{~A} 2$ & $\mathrm{M}_{(03,30)}$ & 22.15 \\
\hline 3 & $\mathrm{~A} 3$ & $\mathrm{M}_{(05,30)}$ & 23.35 \\
\hline 4 & $\mathrm{~A} 4$ & $\mathrm{M}_{(07,30)}$ & 23.95 \\
\hline 5 & $\mathrm{~A} 5$ & $\mathrm{M}_{(10,30)}$ & 25.45 \\
\hline 6 & $\mathrm{~A} 6$ & $\mathrm{M}_{(12,30)}$ & 24.20 \\
\hline 7 & $\mathrm{~A} 7$ & $\mathrm{M}_{(15,30)}$ & 22.25 \\
\hline
\end{tabular}

Table -5: Average Compressive Strength of Modified Mortar after 14 Days Curing

\begin{tabular}{|l|l|l|l|}
\hline S.No & Mix Designation & Mix Type & $\begin{array}{l}14 \text { Days Average } \\
\text { Compressive Strength }\end{array}$ \\
\hline & & $\mathrm{M}_{(\mathrm{X}, \mathrm{Y})}$ & MPA \\
\hline 1 & $\mathrm{~A} 1$ & $\mathrm{M}_{(00,00)}$ & 28.45 \\
\hline 2 & $\mathrm{~A} 2$ & $\mathrm{M}_{(03,30)}$ & 29.20 \\
\hline 3 & $\mathrm{~A} 3$ & $\mathrm{M}_{(05,30)}$ & 31.55 \\
\hline 4 & $\mathrm{~A} 4$ & $\mathrm{M}_{(07,30)}$ & 32.10 \\
\hline 5 & $\mathrm{~A} 5$ & $\mathrm{M}_{(10,30)}$ & 34.65 \\
\hline 6 & $\mathrm{~A} 6$ & $\mathrm{M}_{(12,30)}$ & 32.80 \\
\hline 7 & $\mathrm{~A} 7$ & $\mathrm{M}_{(15,30)}$ & 30.75 \\
\hline
\end{tabular}


Table -6: Average Compressive Strength of Modified Mortar after 21 Days Curing

\begin{tabular}{|l|l|l|l|}
\hline S.No & $\begin{array}{l}\text { Mix } \\
\text { Designation }\end{array}$ & Mix Type & $\begin{array}{l}\text { 21 Days Average } \\
\text { Compressive } \\
\text { Strength }\end{array}$ \\
\hline & & $\mathrm{M}_{(\mathrm{X}, \mathrm{Y})}$ & MPA \\
\hline 1 & $\mathrm{~A} 1$ & $\mathrm{M}_{(00,00)}$ & 35.40 \\
\hline 2 & $\mathrm{~A} 2$ & $\mathrm{M}_{(03,30)}$ & 35.95 \\
\hline 3 & $\mathrm{~A} 3$ & $\mathrm{M}_{(05,30)}$ & 37.20 \\
\hline 4 & $\mathrm{~A} 4$ & $\mathrm{M}_{(07,30)}$ & 38.65 \\
\hline 5 & $\mathrm{~A} 5$ & $\mathrm{M}_{(10,30)}$ & 39.70 \\
\hline 6 & A6 & $\mathrm{M}_{(12,30)}$ & 37.85 \\
\hline 7 & A7 & $\mathrm{M}_{(15,30)}$ & 35.25 \\
\hline
\end{tabular}

Table -7: Average Compressive Strength of Modified Mortar after 28 Days Curing

\begin{tabular}{|l|l|l|l|}
\hline S.No & $\begin{array}{l}\text { Mix } \\
\text { Designation }\end{array}$ & $\begin{array}{l}\text { Mix } \\
\text { Type }\end{array}$ & $\begin{array}{l}28 \text { Days Average } \\
\text { Compressive } \\
\text { Strength }\end{array}$ \\
\hline & & $\mathrm{M}_{(\mathrm{X}, \mathrm{Y})}$ & MPA \\
\hline 1 & $\mathrm{~A} 1$ & $\mathrm{M}_{(00,00)}$ & 42.30 \\
\hline 2 & $\mathrm{~A} 2$ & $\mathrm{M}_{(03,30)}$ & 42.95 \\
\hline 3 & $\mathrm{~A} 3$ & $\mathrm{M}_{(05,30)}$ & 43.25 \\
\hline 4 & $\mathrm{~A} 4$ & $\mathrm{M}_{(07,30)}$ & 44.60 \\
\hline 5 & $\mathrm{~A} 5$ & $\mathrm{M}_{(10,30)}$ & 45.95 \\
\hline 6 & $\mathrm{~A} 6$ & $\mathrm{M}_{(12,30)}$ & 43.50 \\
\hline 7 & $\mathrm{~A} 7$ & $\mathrm{M}_{(15,30)}$ & 41.95 \\
\hline
\end{tabular}

Table -8: Average Compressive Strength of Modified Mortar after 56 Days Curing

\begin{tabular}{|l|l|l|l|}
\hline S.No & $\begin{array}{l}\text { Mix } \\
\text { Designation }\end{array}$ & Mix Type & $\begin{array}{l}56 \text { Days Average } \\
\text { Compressive } \\
\text { Strength }\end{array}$ \\
\hline & & $\mathrm{M}_{(\mathrm{X}, \mathrm{Y})}$ & MPA \\
\hline 1 & A1 & $\mathrm{M}_{(00,00)}$ & 48.10 \\
\hline 2 & A2 & $\mathrm{M}_{(03,30)}$ & 48.90 \\
\hline 3 & A3 & $\mathrm{M}_{(05,30)}$ & 49.25 \\
\hline 4 & A4 & $\mathrm{M}_{(07,30)}$ & 52.65 \\
\hline 5 & A5 & $\mathrm{M}_{(10,30)}$ & 54.80 \\
\hline 6 & A6 & $\mathrm{M}_{(12,30)}$ & 47.95 \\
\hline 7 & A7 & $\mathrm{M}_{(15,30)}$ & 45.40 \\
\hline
\end{tabular}


Variation in average Compressive strength of modified mortar samples after 7, 14,21,28,56 day curing is shown in graphs below.

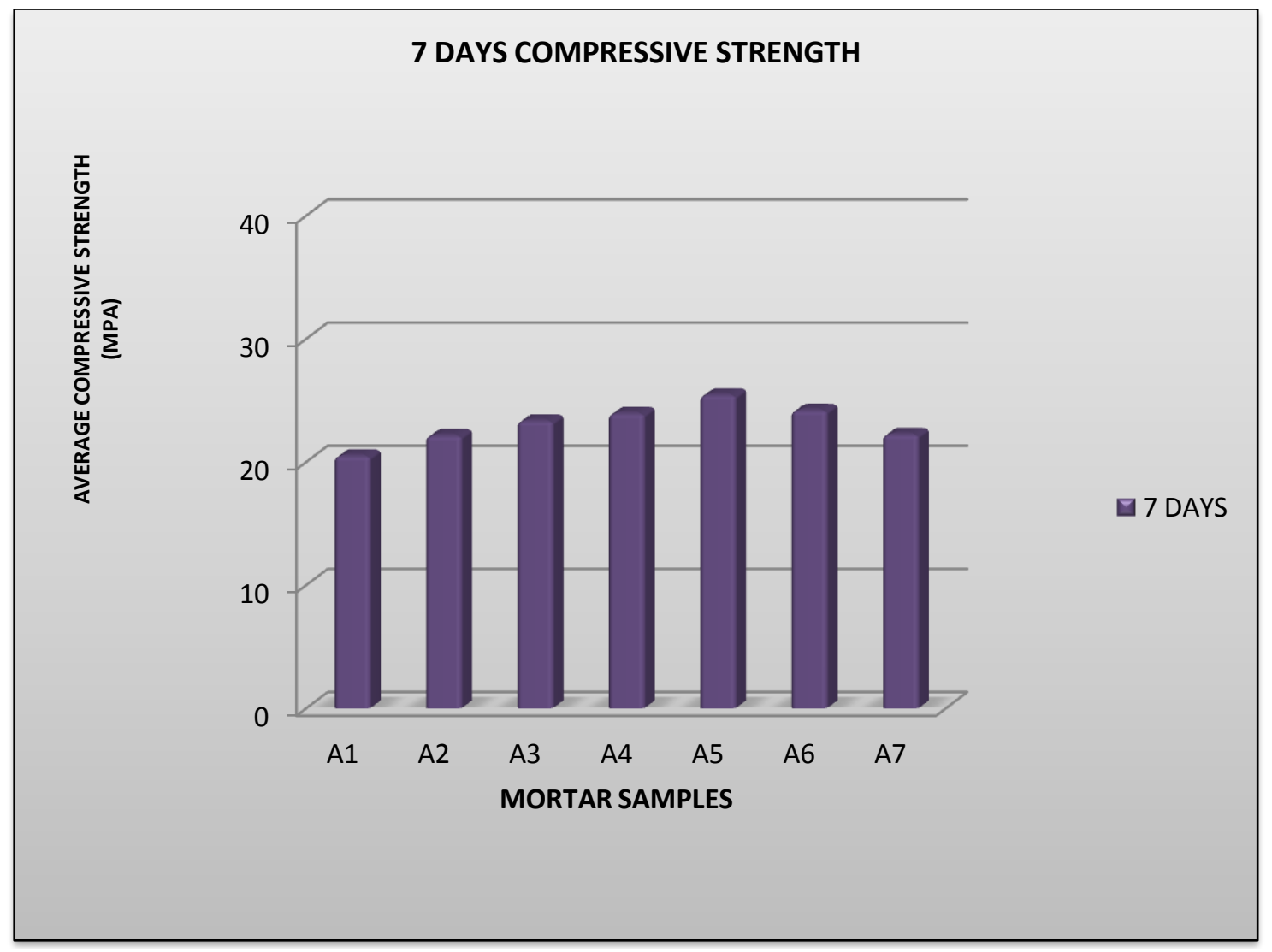

Graph 1: Graph Showing Variation in Compressive Strength of Different Modified Mortar Samples After 7 Days Curing Period

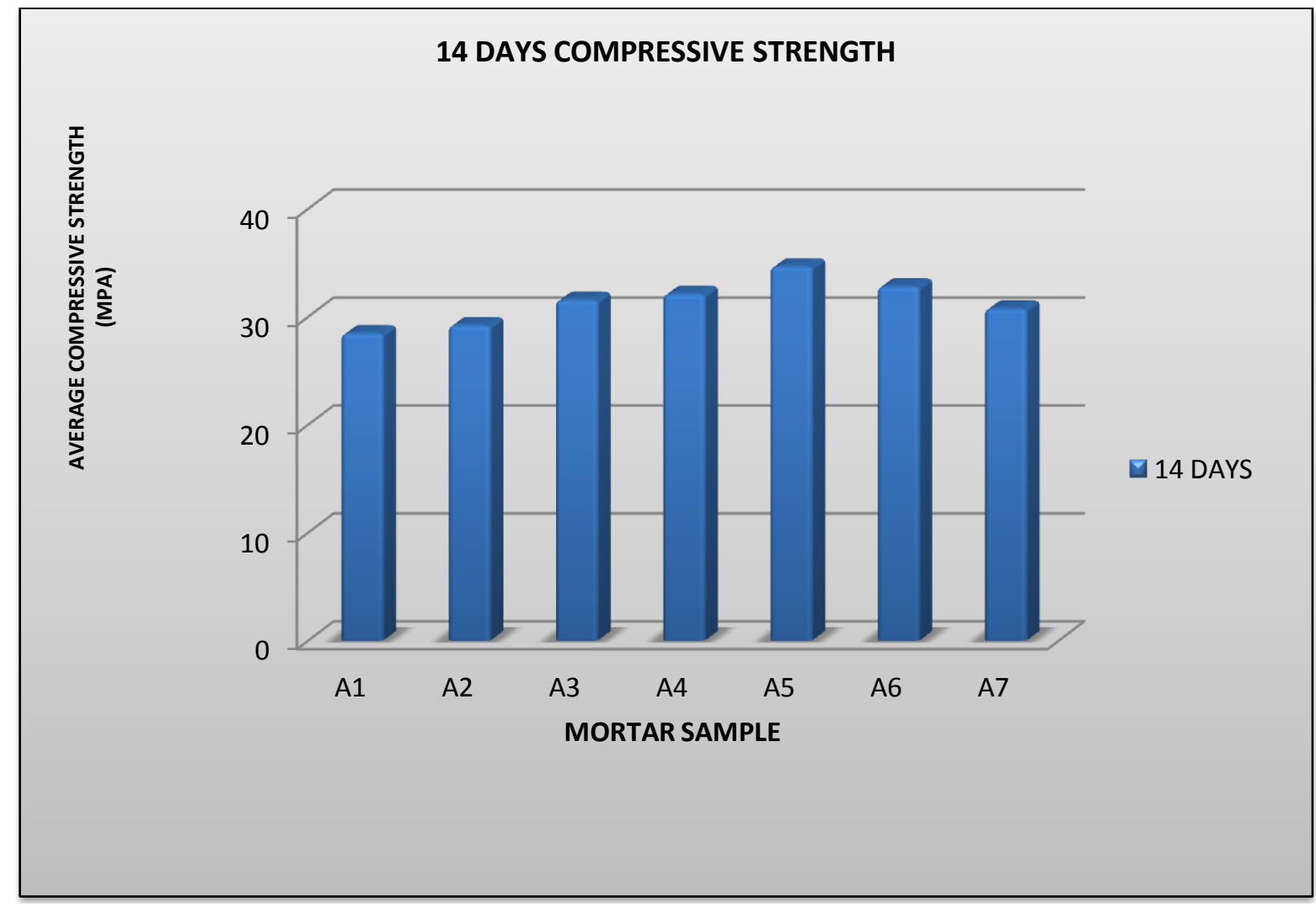

Graph 2: Graph Showing Variation in Compressive Strength of Different Modified Mortar Samples After 14 Days Curing Period. 


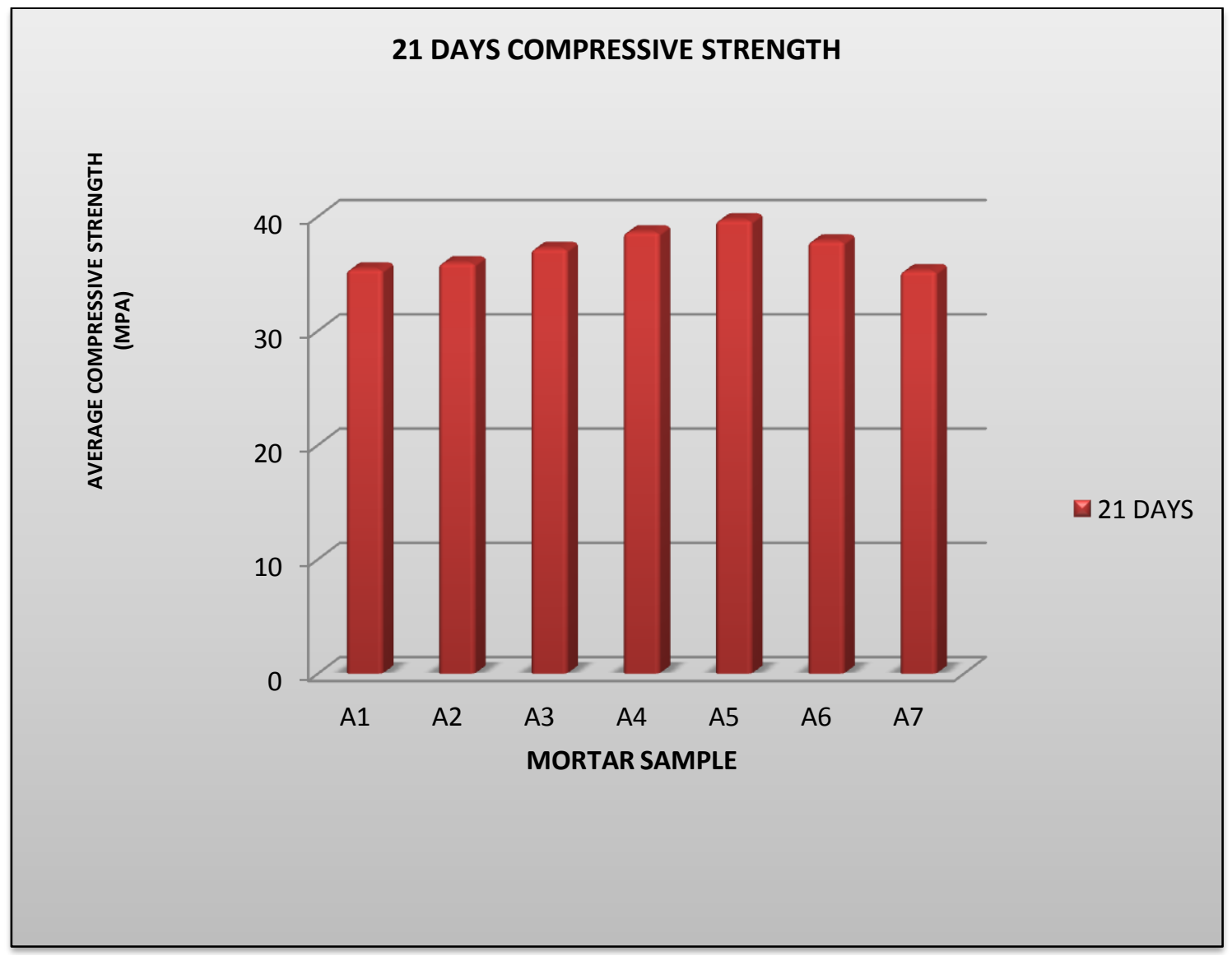

Graph 3: Graph Showing Variation in Compressive Strength of Different Modified Mortar Samples After 21 Days Curing Period.

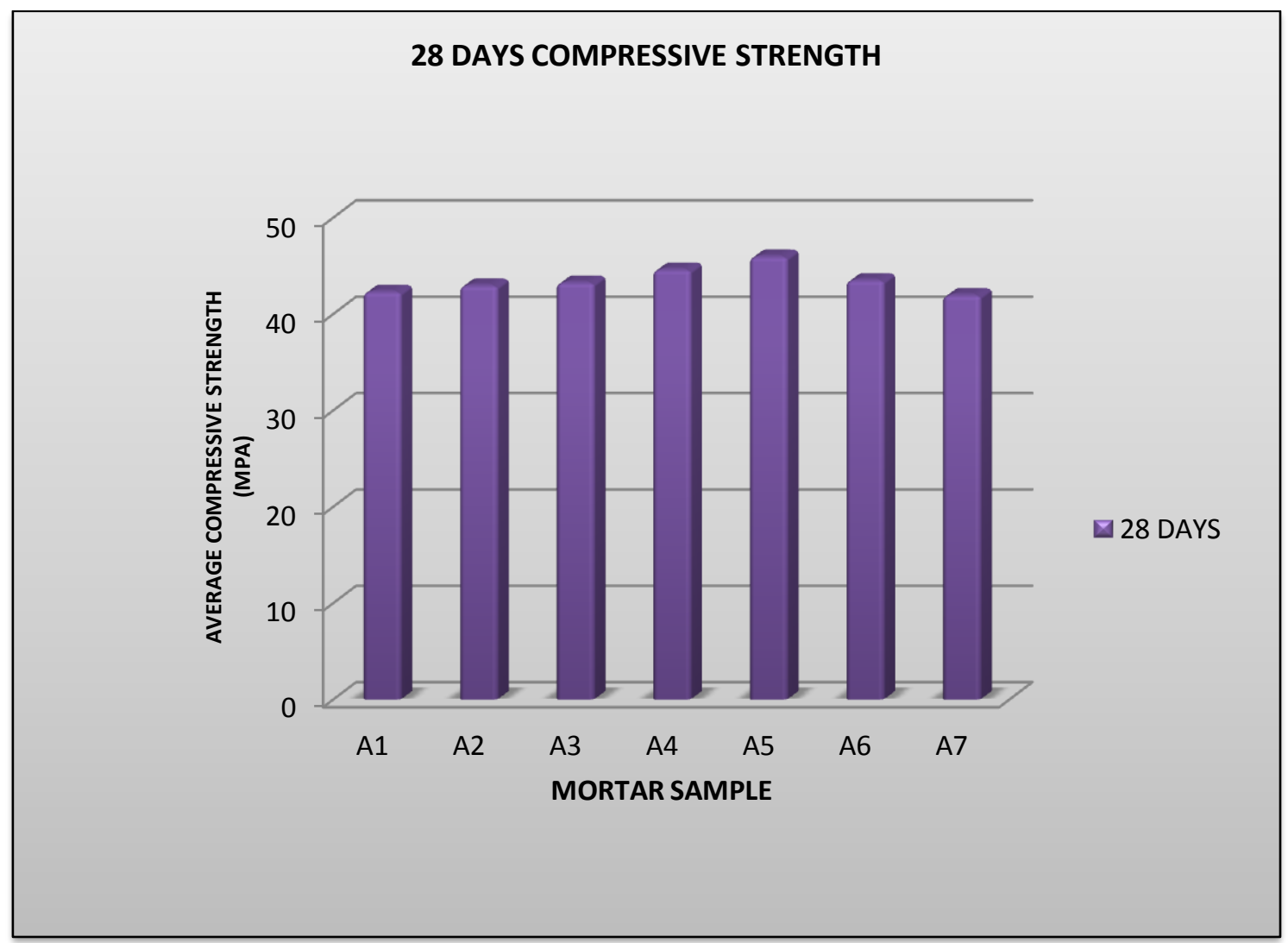

Graph 4: Graph Showing Variation in Compressive Strength of Different Modified Mortar Samples After 28 Days Curing Period. 


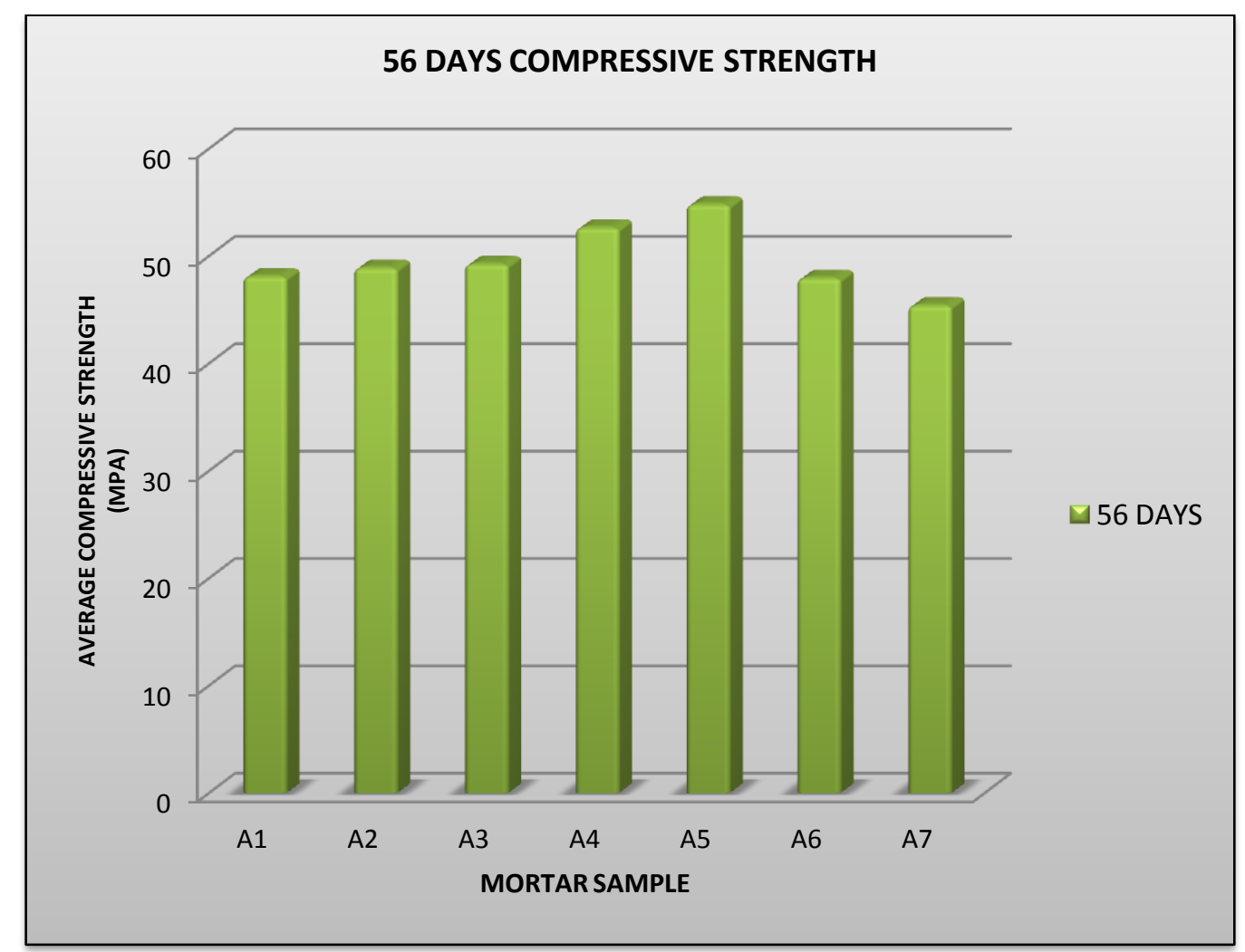

Graph 5: Graph Showing Variation in Compressive Strength of Different Modified Mortar Samples After 56 Days Curing Period. Comparison between the strength developments in various mortar samples have been after curing has been shown below in Graph 6

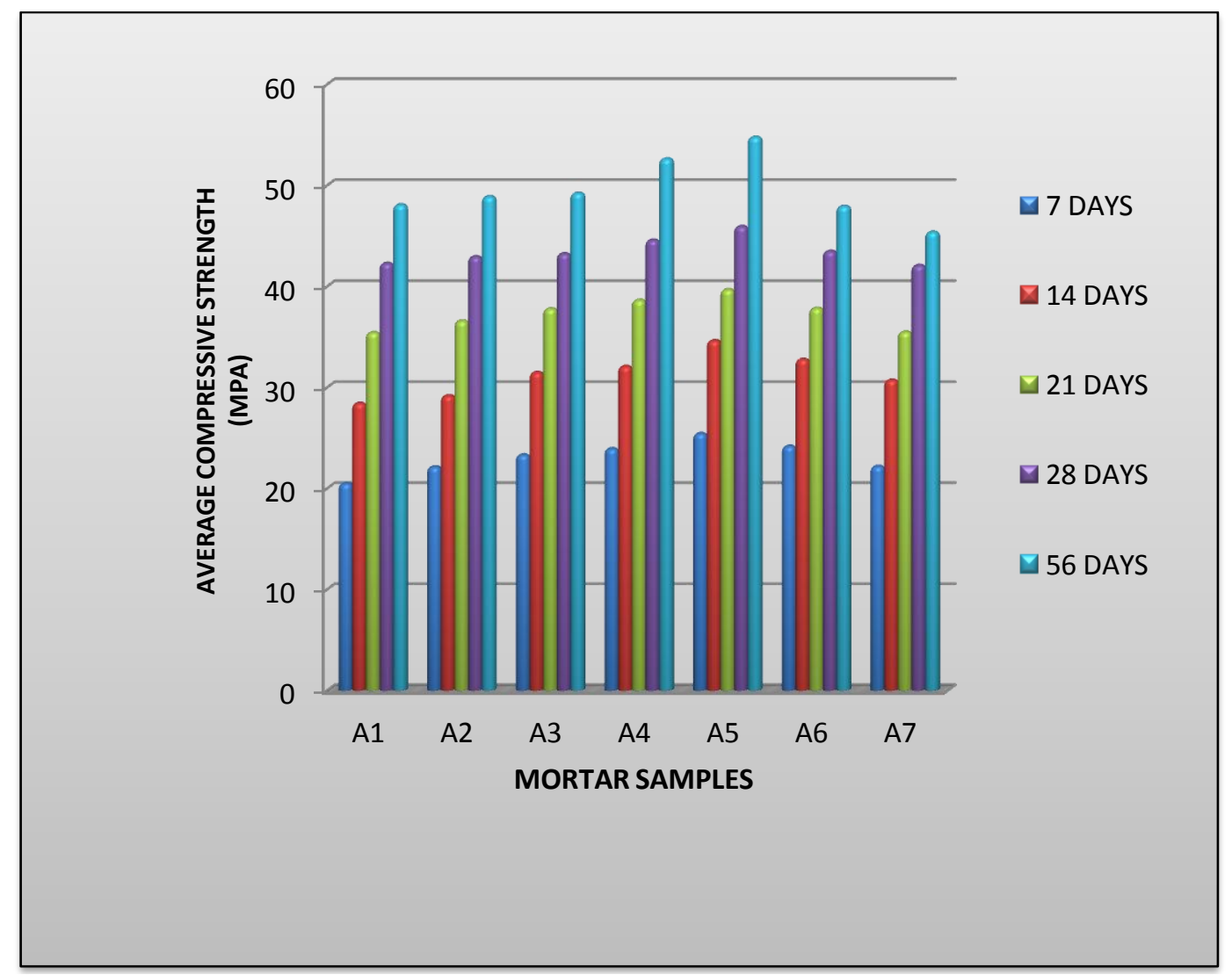

Graph 6: Graph Showing Variation in Compressive Strength of Different Modified Mortar Samples 


\subsection{Water Absorption Test}

Water absorption is the measurement of the water proofness of the mortar mix. All the mixes were subjected to water absorption test at the end of curing period of 28 days after demoulding. The $70.7 \mathrm{~mm} \times 70.7 \mathrm{~mm} \times 70.7 \mathrm{~mm}$ size cube after casting were immersed in water for 28 days curing. These specimens were then oven dried for 24 hours at the temperature $85^{\circ} \mathrm{C}$ until the mass became constant and again weighed. This weight was noted as the dry weight (W1). After that the specimen was kept in water at $85^{\circ} \mathrm{c}$ for 24 hours. Then this weight was noted as the wet weight (W2).Now using formula, water absorption of various mortar samples is calculated.

$$
\text { Water absorption }=[(\mathrm{W} 2-\mathrm{W} 1) / \mathrm{W} 1] \times 100
$$

Where,

$\mathrm{W} 1$ = Oven dry weight of cubes in grams

$\mathrm{W} 2$ = After 24 hours wet weight of cubes in grams

The results so obtained are listed in table below

Table -8: Water absorption of various mortar cube samples

\begin{tabular}{|l|l|l|l|}
\hline S.No & $\begin{array}{l}\text { Mix } \\
\text { Designation }\end{array}$ & Mix Type & $\begin{array}{l}\text { WATER } \\
\text { ABSORPTION }\end{array}$ \\
\hline & & $\mathrm{M}_{(\mathrm{X}, \mathrm{Y})}$ & $(\%)$ \\
\hline 1 & A1 & $\mathrm{M}_{(00,00)}$ & 16.45 \\
\hline 2 & A2 & $\mathrm{M}_{(03,30)}$ & 16.9 \\
\hline 3 & A3 & $\mathrm{M}_{(05,30)}$ & 17.25 \\
\hline 4 & A4 & $\mathrm{M}_{(07,30)}$ & 18.1 \\
\hline 5 & A5 & $\mathrm{M}_{(10,30)}$ & 18.75 \\
\hline 6 & A6 & $\mathrm{M}_{(12,30)}$ & 19.2 \\
\hline 7 & A7 & $\mathrm{M}_{(15,30)}$ & 19.85 \\
\hline
\end{tabular}

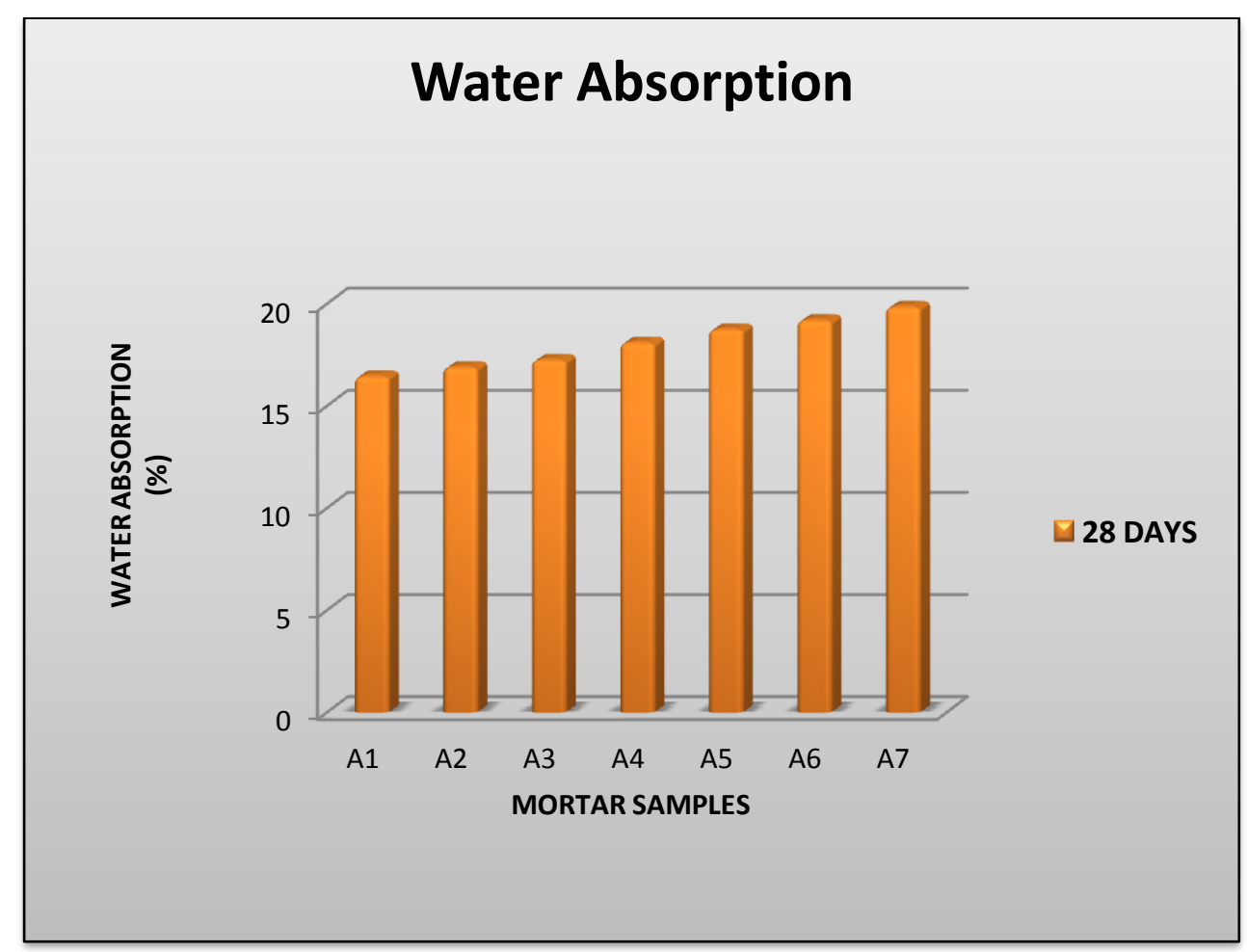

Graph 7: Graph showing variation in water absorption of different modified mortar samples. 


\section{CONCLUSION}

The effect of addition of fly ash and mill scale wastes in cement mortar was studied and conclusions based on the results obtained in the experiments are as follows. :

1) Due to inclusion of mill scale and fly ash waste as fine aggregate replacement, the mortar made was found to light weight in nature.

2) The compressive strength was observed to increase up to $10 \%$ mill scale and $30 \%$ fly ash replacement, as compared to normal mortar, than as the percentages of wastes increases the compressive strength decreases.

3) The water absorption of mortar formed by addition of fly ash and mill scale wastes was found to be higher than normal mortar \& it increases by increasing the percentage of wastes in cement mortar.

4) The mortar formed by addition of fly ash and mill scale wastes was found to be economical than normal mortar.

\section{REFERENCES}

[1] Trakool Aramraks (2006), "Experimental Study of Concrete Mix with Bottom Ash as Fine Aggregate in Thailand", SEAMEO-INNOTECH.

[2] Young; Rom D. and Norris; David, (2004) "Process for using mill scale in cement clinker production", US Patent No. 6709510.

[3] Pradip, D. Vaidyanathan, P. C. Kapur and B. N. Singh, (1990), "Production and properties of alinite cements from steel plant wastes", Cement and Concrete Research, Volume20, Issue 1, January, Pages 15-24..

[4] M. Z. Chen, M. K. Zhou and S. P. Wu, "Optimization of Blended Mortars Using Steel Slag Sand," Journal of Wuhan University of Technology, Material Science

[5] T. R. Naik, S. S. Singh, M.P. Tharaniyil and R. B. Wendfort, "Application of Foundry by Product Materials in Manufacture of Concrete and Masonry Products," ACI Materials Journal, Vol. 93, No. 1, 1996, pp. 41-50.Edition, Vol. 3, 2007, pp. 741-744.

[6] Y.-F. Li, Y. Yao and L. Wang, "Recycling of Industrial Waste and Performance of Steel Slag Green Concrete," Journal of Central South University Technology, Vol. 16, No. 5, 2009, pp. 768-773

[7] Ratchayut Kasemchaisir and Somnuk Tangtermsirikul (2008), "Properties of SelfCompacting concrete incorporating Bottom Ash as a Partial Replacement of Fine Aggregate", Science Asia, Vol. 3 pp. 87-95.

[8] Chai Jaturapitakkul and Raungrut Cheerarot, (2003), "Development of Bottom Ash as Pozzolanic material", Journal of materials in civil engineering, Vol. 15, pp. 48-53.

[9] IS 2250:1981 (reaffirmed 2005) - Code of Practice for Preparation and Use of Masonry Mortars.
[10] IS 8112: 1989 Specification for 43 grade Ordinary Portland Cement. Manak Bhavan New Delhi.

[11] IS 2116 (1980) Specification for Sand for masonry mortars ( First Revision), Manak Bhavan New Delhi, India

[12] Miranda L. , Selmo S. (1999). "Evaluation of the effect of recycled waste on the properties of hardened mortars, by rational proportioning procedures." Proc., III Brazilian Symp. of Mortars Technology (SBTA), IPT, Vitoria, Brazil, 583-594

[13] Moriconi G, Corinaldesi V Antonucci R (2003) "Environmentally-friendly mortars: a way to improve bond between mortar and brick", Material and Structure, 36(10), pp-702-708.

[14] A B. Tardale, S S Patil, N. J. Pathak, (2011), "Feasibility Study of Replacement of Cement and Sand in Concrete and Mortar by ECOSPHERE Material", International Journal of Earth Sciences and Engineering, Volume 04, No 06 SPL, October 2011, pp-920-923 